\title{
Teaching Indonesian Language Interestingly
}

\author{
Larasati \\ \{larasati@upgris.ac.id\}
}

Universitas PGRI Semarang, Indonesia

\begin{abstract}
Until now, Indonesian language subjects are still looked down upon by students. Most students, be that in elementary, junior, as well as senior high school consider Indonesian language as a subject that is not important because it is used daily. The next fact is that students underestimate when the teacher teaches, classes are rowdy during the learning process, and students are reluctant in doing assignments. This condition is very contradictory to the strategic position of Indonesian subjects as compulsory subjects for students of all levels and is very important essentially because these are subjects that must be tested on national examinations. This paper describes how to prepare enticing Indonesian language learning. Based on the studies and analysis conducted, it can be concluded that Indonesian language learning that focuses on textual and written communication skills requires an effort to be interesting. Some things that teachers need to do to make Indonesian language learning interesting includes: (1) Mastering Basic Teaching Skills, (2) Preparing attractive learning designs, (3) Preparing traditional and electronic learning media, (4) Choosing appropriate learning methods, (5) Continue to develop themselves through training and seminars, and (6) Improving literacy skills. Based on the conclusions obtained, it is recommended that: (1) Indonesian Language teachers should immediately improve and do 6 things so that Indonesian Language learning is interesting and (2) teachers of other subjects can adopt 6 things the analysis of this paper has found.
\end{abstract}

Keywords: Teaching, Indonesian Language Subject, Enticing Learning

\section{Introduction}

Teacher is the determining factor for the success of education [1]. With their very strategic position, it can be said that the main factor determining the success of learning is the teacher. Howsoever may the lesson be conducted; the teacher is the one most responsible. Naturally, very high expectations are addressed to teachers so that the image of education in Indonesia is bright and charming. Thousands of students await the help and compassion of knowledge and attention from a teacher. This is where, a very high bargaining position is occupied by a teacher. Not surprisingly then that a Japanese emperor named Hirohito in 1945 after a bombing that resulted in the destruction of Hiroshima and Nagasaki, the question that first arises is how many teachers are still alive [2]. Such is the importance of a teacher, so it is not surprising that Krishna [1] places teachers as the noblest of profession.

However, reality is not as beautiful as perception. Even though they have a very strategic position in maintaining the goal of the nation's progress, the findings in the field are sufficient to be a source of introspection for all elements of education, especially teachers. Jailani [3] reported on the teaching worthiness of teachers mentioned that 21,07\% of Public Elementary School teachers were eligible to teach, 28,94\% of Private Elementary School teachers were eligible to teach. Furthermore, 54,12\% of Public Junior High School teachers were declared 
eligible to teach, and $60,99 \%$ of Private Junior High School teachers were declared eligible to teach. Next, for Public Senior High School teachers, as many as 65,29\% were declared eligible to teach, and $64,73 \%$ of Private Senior High School teachers were declared eligible to teach. The report carries a very deep moral message. That is, the remaining percentage as stated in the teaching worthiness report is a category of teachers who are lacking, or even not worth teaching. In plain view, a temporary conclusion can be made that as much as 78,93\% of Public Elementary School teachers are unfit to teach and as much as $71,06 \%$ Private Elementary School teachers fall into the category of unfit for teaching. Furthermore, it was found that $45,88 \%$ of Public Junior High School teachers were unfit to teach and 39,01\% of Private Junior High School teachers were declared unfit to teach. Then, $34,71 \%$ of Public Senior High School teachers were declared unfit to teach and 35,27\% of Private Senior High School teachers unfit to teach.

According to the facts above, it is no exaggeration that Abas [4] gives in-depth criticism in his writing entitled "Disoriented Teacher Management" which states that teacher certification programs do not have a good effect on education. Learning outcomes through tests conducted on students taught by certified teachers and students taught by teachers who are not certified in Indonesian, Mathematics, English, and Science subjects do not show significant differences. Likewise, the level of mastery and material knowledge of students taught by certified teachers and uncertified teachers are the same.

Related to the phenomenon of low teacher competence, especially Indonesian language subjects, it is not surprising that the students' interest in these subjects is really unsatisfactory. Sitorus's [5] analysis in Kompas daily newspaper revealed that in the field, students felt bored with Indonesian language lessons. Not many of them are waiting for Indonesian language lessons to commence in their class. Students feel the lesson is not very interesting so that during class hours, a lot of them are daydreaming and busy with their own activities. What a worrying phenomenon.

If until now Indonesian language lessons are considered by students as easy and not too important but instead become a stumbling block for graduation [6], then one of the figures suspected of carrying the heavy weight is the Indonesian language teacher. Why? Because after all it is the teacher who delivered, accompanied, and created an atmosphere of learning Indonesian language for their students.

This paper examines how teachers should teach Indonesian language subjects interestingly so that students have a positive impression and have satisfying learning outcomes.

Indonesian language is a subject for all levels of education. Students from elementary to college level get compulsory Indonesian subjects. Seeing its very strategic position, making these subjects considered as important and is tested nationally at every level. The main purpose of this Indonesian language lesson is to provide students with language skills. Thus, indicators of achievement for this subject are students to be skilled in using the language, can communicate well, and have good literacy skill.

Slamet [7] says that the focus of language teaching is not the teaching of language, but rather the teaching of language skills. This statement is sufficient to be a mutual understanding that teachers who only teach concepts about language will never be successful as language teachers because students will only understand the definition, characteristics, and variety of languages without being able to use the language skillfully. Concepts are needed only as a complement in the context of the focus of the material being taught.

In connection with the case above, Atmazaki [8] revealed that the focus of Indonesian language learning is aimed at making students able to communicate efficiently and effectively according to ethics. Indonesian language learning is also directed at students' skill in communicating verbally and textually. It seems that creative methods and strategies from the 
teachers are needed so that the learning objectives are well achieved according to the target. It is not enough for a teacher to provide written lesson plans only. More than that, applying what is written in the lesson plan can be realized well with the right strategy.

In the application of realizing perfect Indonesian Language learning, in the 2013 curriculum, the focus of learning is presented in the form of texts with various variations. The text presented can be oral and written. In textual learning, of course it is required to understand the context and situations that surround the text. Relation to the culture, social, and character of the community that surrounds the text as teaching material.

Also in language learning, Mahsun [9] provides signs that must be known and understood by teachers, namely related to meaning and form. The meaning and form are two elements that must be fulfilled simultaneously in using language. However, the element of meaning is the main component that must be present in the formation of language. For this reason, critical, systematic, controlled thinking is an element that must be brought together.

\section{Methods}

This paper uses the literature review method which is done by reading, studying, and examining research results combined with pure ideas from the author. As a complement to the analysis results, this study utilizes textbooks, seminars, papers and daily printed media.

\section{Results of Study}

After reviewing various references related to the topic of study, the results of the study are described in a straightforward manner on how a teacher prepares and does important things in Indonesian language learning so that students feel interested and the expected results are in accordance with curriculum requirements.

\subsection{Teaching Indonesian Language Interestingly}

To achieve an interesting learning atmosphere, teachers must pay attention to the factors that cause learning success. Kunandar [10] said that the success of a learning is influenced by at least six factors, including; (1) the student's personality as the main target of learning, (2) the teacher as the learning activator, (3) the expected learning objectives, (4) learning material supporting learning, (5) ease in achieving teaching material, and (6) the atmosphere at the time of learning. Thus, the teacher becomes an important factor in the students learning process.

It is the teacher's job to be the activator and controller of learning. The good and the bad of learning in class are greatly influenced by the figure of the teacher. It also applies in learning Indonesian language. The role of the Indonesian language teacher in bringing an atmosphere of joy, love, and enthusiasm is greatly influenced by the Indonesian language teacher himself/herself. In his/her role as an Indonesian language teacher, it is natural for teachers to design, plan, and carry out optimal learning.

There are a number of things that Indonesian language teachers need to do in order to realize an interesting teaching, including mastering basic Indonesian language teaching skills, preparing attractive learning designs, preparing traditional and electronic learning media, 
choosing appropriate learning methods, continuing to develop themselves through training and seminar, and having good literacy skills. Some of these are explained below:

\subsubsection{Mastering Basic Teaching Skills}

Ngatmini et al. [11] research on the ability of Indonesian Language teachers to apply basic teaching skills is quite a punch in the world of teachers, especially Indonesian Language teachers. Imagine, a study with research subjects of junior and senior high school teachers in the city of Semarang revealed that the average competence value of Indonesian language teacher in junior and senior high school level in the city of Semarang was in the $\mathrm{C}$ category with a percentage of 59\%. The results of these studies indirectly instruct teachers, prospective teachers, and even LPTK (Educational Institutions for Educational Labor) to produce prospective teachers must sort itself up. The basic skills for teacher's work are far from safe or reasonable. If the teacher has low basic abilities in applying basic teaching skills, then it can be learning output can be imagined. Therefore, there is no other reason for Indonesian teachers not to master and improve their basic teaching skills.

There are at least 8 basic teaching skills that must be possessed by teachers [12], namely (1) Question Skills, (2) Reinforcement Skills, (3) Variation skills, (4) Explaining skills, (5) (Set Induction Skills), (6) Skills to guide small group discussions, (7) Skills to manage classes, and (8) Individual learning skills.

First, Question Skills. Questioning skill is important for Indonesian language teachers. Questioning activity is not only to test students in order to take scores, more than that it is also to find out how far the material being learned is absorbed by students. The teacher must have a questioning style that does not make students tense, depressed, or even frightened. Questions do not have to be explored with question words directly, but can also be done by asking students to recount the activities of the day. Then, the teacher asks other students to add or disprove their friends report.

Questioning activities can also be done in the middle of learning. The teacher asks in order to invite students to think critically. Questions are also conducted to stimulate students to relate learning themes to the experiences students have. Students are given the opportunity to convey sufficient information according to the theme. This is done because the teacher's role as a facilitator facilitates information opportunities about learning themes as needed. After being considered sufficient, the teacher aligns and perfects the information according to the theme presented in the learning.

Second, Reinforcement skill. Reinforcement is a form of positive response from Indonesian teachers to students' responses to the learning provided. Reinforcement can be in the form of material repetition and alignment; it can also be in the form of a positive response to student answer. When the teacher explains the material, that's where the transfer of information occurs which then brings out the student's response. Student responses can be questions, rebuttal, or answers to teacher questions. This is where a language teacher plays his/her role. To reiterate, the key to success is the ability to communicate with students. A teacher needs to provide reinforcement in the form of rewards, such as giving praise, expressions with the word 'good' while giving a thumbs up or a phrase like 'smart' to students. Praise needs to be given to make students happy and proud so that they feel valued [13].

Reinforcement can also be a punishment. However, the impact of punishment that are not educational in nature will be worse for students so there is no need for teachers to do that if the conditions can still be overcome. Reinforcement activities will be more meaningful if the teacher gives motivation to students. This motivational sentence will be imprinted in the child's 
brain and will be expressed in the form of positive behavior. Rahmayanti's [14] research on Indonesian language motivation and achievement revealed that the better the teacher's motivation towards students had an effect on students' Indonesian language learning achievement.

Third, the skill to make variations. What is meant by variation is learning activities presented by the teacher are not monotonous in terms of any method, media, explanation method, expression, or evaluation. Teachers who carry out learning with limited styles and patterns will surely bore students easily, or even make them uncomfortable in the classroom. A simple example of monotony in terms of method is the teacher always lectures while giving lessons in all basic competencies. Learning to write explanatory texts, reading poetry, and analyzing literary works too is carried out using the same method, namely lectures. What happens is the results reality is not as expected. This is because the teacher is more focused on delivering the material rather than the content of the desired competency in the syllabus so that students absorb theoretical material more than the practice of writing, reading, and analyzing as basic competencies is intended.

Fourth, explaining skills. Explaining is an activity that is inseparable as the task of a teacher. The style and the way the teacher explain will be recorded by students which are then processed into knowledge. Thus, this skill to explain material has a very strategic position in bringing students to understand and absorb the teacher's conveyed information. A wise teacher will give students some room to digest their explanations, and then provide an opportunity to respond to what has been said. Here is where two-way communication takes place which is the right time for the teacher to know to what extent the material can be absorbed.

Fifth, Set Induction Skills. Skillfully opening and closing lessons is a routine activity that is always done by the teacher in lesson. The activity of opening a lesson is not just a matter of formality so that all Indonesian Language teachers find it easy to do so. Opening is the gateway to a successful learning. If the initial round is successful, it is not impossible that the next process will be easy too. For the right teacher, initiating learning is not just lip service without a theme, but he/she is able to communicate warmly and friendly while focusing communication directed at the basic competence that will be taught. This activity is appropriately referred to as apperception. This apperception activity aims to stimulate students to be ready with the learning themes to be presented. It is not convenient for a teacher to enter the class and immediately give materials without a warm start to students.

Likewise, learning activities will be without impression if the teacher hastily closed with greetings. A moment of contemplation is needed, such as evaluating, motivational sentences, messages, and impressions, then the teacher closes the lesson. Evaluation needs to be given even though it is simple because the teacher can directly know the attitudes, responses, and behavior of students currently learning [15]. If the closing activity is encouraging, students can be sure to give a positive impression of learning at that time. As a result, students are eager to learn and look forward to continuing the material at the next meeting.

Sixth, skills to guide small group discussions. This activity is a form of teacher's attention to student learning discussions in small scopes (two to four people). Indonesian language teachers need to know one by one student responses to the material presented. This activity can be done by compiling a learning observation sheet containing a row of criteria for students' conditions in learning Indonesian filled in by the teacher by checking or commentary.

Monitoring in the form of small discussion activities is carried out while learning takes place with direct observation. The teacher can also do this by providing observation sheets and filling them out while monitoring the course of the discussion. Classes are grouped in small groups that allow teachers to monitor easily. The teacher can ask students in pairs of two people, 
or in groups with a maximum of five people. Activities are carried out by explaining the rules first. The aim is to make students know what they have to do while participating in the discussion activities.

In the learning process for these small groups, students are prepared to become members of the community who will face and communicate with others. Indirectly they learn to convey ideas to others, negotiate, submit input, and find solutions to a problem.

Seventh, class management skills. This activity is a form of classroom management activities. Teachers who do well in teaching preparation can certainly enter the classroom with bright faces and can convey the material smoothly so that the class will be easy to manage. In class management it can be seen how a teacher can control the classroom atmosphere. Classes are focused on learning, student activities are focused on learning content, and class atmosphere is under the teacher's control. The teacher really has authority in front of students.

It is possible that the atmosphere of the class will be noisy. Students don't always have to sit nicely and look down. However, the noisy classes occurring are busy with learning. A simple example is when the teacher teaches basic competence of 'analyzing read short stories' in the classroom.

Eighth, individual learning skills. This is in the form of teacher attention to individual student learning conditions. Indonesian language teachers need to know one by one student responses to the material presented. This activity can be done by compiling a learning observation sheet containing a row of criteria for student conditions in learning Indonesian language. Thus, in addition to the teacher providing learning, transfer of material, and character, he/she also observes the responses of his students one by one.

The description of individual student responses will be a note for the teacher to provide feedback to students. This response will be checked with the results of the learning evaluation that occurred right then and there. The teacher will give a response back to those whose evaluation scores are low and responses are not good. The teacher also gives a response back to those whose learning response is poor even though the evaluation value is good. This is an important note for teachers to do contemplation or reflection material and input in conducting further learning.

\subsubsection{Preparing Interesting Learning Designs}

One of the characteristics of professional teacher according to Hunt in Rosyada [16] is for them to have expertise in planning and managing classes. Planning for learning design is contained in the Lesson Plan (RPP) made by the teacher. This lesson plan must be prepared and understood by the teacher before teaching. In this way, learning takes place with careful planning, not the other way around. Of course, by preparing the lesson plan the teacher mentally knows the Basic Competence (KD) to be taught, sets learning objectives and indicators, prepares learning material, prepares learning steps, and determines evaluation. It's not enough to just write or prepare. The teacher must understand well what has been planned. In front of students, the teacher instructs in accordance with the prepared lesson plans. If the condition of the class is not as planned - for example there is an unexpected event - the teacher can immediately adapt and make decisions while still paying attention to the points in the lesson plan. The teacher will also control the class easier because everything he/she needs in teaching presently has been mastered.

The results of Leonard's study [17] are enough to astonish educational practitioners. In a study of 60 teachers, $70 \%$ of them did not prepare the learning process properly. The teacher focuses more on the learning material, without heeding the objectives of the learning itself. The 
phrase 'What matters is that teaching material is done' still dominates the mindset of the teachers so it is not surprising if what happens in the classroom is just a view of writing material from a textbook that is copied into the students' notebook.

It can be imagined if a teacher enters the classroom without having a lesson plan. Of course, the material is not well prepared, the learning methods are patched up, only giving assignments and lectures crudely. This condition is very alarming. The fate of the nation's children who are awaiting help for their teachers' knowledge and guidance, do not get their rights properly. It is very clear that the students and the state are harmed. Students as the state's asset that should be well prepared through school institutions, obtain character education, knowledge, appropriate material as a provision to face the future and fill development in reality it is not so because of unprofessional teachers.

Learning will be direct if carefully prepared. The preparation is contained in the scenario or learning design that is covered in the lesson plan.

The Indonesian language teacher is not an obedient craftsman who only obeys the tasks as outlined in the curriculum and handbook published by the National Education Agency. However, the teacher must be creative, dare to develop, design, find, and formulate their own materials that will be transferred to students. If this happens, it is not impossible that learning Indonesian will be a very interesting and eagerly awaited moment by students. Indonesian Language Teachers are not only as language instructors, but also as agents to change students' mindset positively as part of the community. He/she deserves to be called as a competent teacher in his field, which Giroux as quoted by Suparno [18] termed intellectual information.

With strong character and design, Indonesian Language teachers can be a bridge for students to achieve what they want. With patience, Indonesian language teachers can not only make students be a teacher, but also artists and designers for their students.

\subsubsection{Preparing Traditional and Electronic Learning Media}

Media is an important tool in learning. With media, teachers can easily transfer the information to students. Without media, instructing teachers will feel dry or not artful. Teachers also only rely on shrewdness in speaking, without regard to the creativity and attractiveness in teaching. The focus of student attention will be directed when the media is presented creatively.

This learning media can be categorized into two types, namely traditional media and electronic media. Traditional media are made manually by the teacher. This media is the result of the teacher's creativity in integrating the material with objects around it so that it can function as a bridge in making it easier for students to digest and understand the material presented. The media can also be done by the teacher by providing teaching aids. This visual aid helps the teacher to facilitate the transfer of information. For example, the teacher uses a visual aid in the form of a hand puppet when teaching fairy tales. Dalyono [19] reminded that learning without the help of teaching aids would make it difficult for students. Thus, the role of the media will have a profound effect on improving student learning achievement.

The electronic media can be advanced by the teacher when he has sufficient mastery of communication information. The teacher can make it in a power point program which is then combined with pictures and videos. The teacher can also present films that fit the basic competence theme to be taught. The provision of this media can be combined with traditional media made by teachers from paper, plastic, beads, and other items that are around and made manually with a creative form. Surely, with an interesting media presentation, students will be happy and interested in Indonesian language lessons. 


\subsubsection{Choosing Appropriate Learning Methods}

It is still trending in every learning research background that teachers still use monotonous learning methods, all the same thing that make the students get bored. The result of this situation is like one-sided learning. Teachers teach and students do not pay attention. This fact is reinforced by the results of Leonard's study [17] of a number of teachers in Jakarta who revealed that the teacher's method of instructing was very monotonous. Teachers do not have creativity in determining learning methods so learning is not interesting. These findings imply that learning methods occupy a very important position in the process of learning success.

The importance of the role of learning method was also revealed in the study of Sumayasa et al. [6] regarding the differences in Indonesian classes taught by traditional methods and classes taught by scientific methods. In his research, students' motivation in scientific classes is better than traditional classes. Thus, it is true the phrase that says that the effort will not betray the results. In the hands of creative teachers, students will also be creative. Conversely, teachers who do not want to change and strive for their own with learning innovations, also produce stagnant students. The next positive impact of the results of the study was the creation of a pleasant Indonesian language learning atmosphere. A touch of the right method will produce the right learning outcomes.

Indonesian Language teachers must be creative in combining methods and the material to be taught. An understanding of the variety of learning methods must be possessed. Teachers are also required to have an understanding of the curriculum, planning, implementation, and evaluation of learning. The learning method is a complement to the four aspects that the teacher must understand. The results of Pujiono's [20] research regarding the readiness of Indonesian teachers in learning become a material for deep reflection for Indonesian teachers. In his research, Pujiono [20] said that the readiness of Indonesian teachers in lesson planning was $68,69 \%$. Thus, it can be understood that less than $70 \%$ of Indonesian language teachers are ready to plan a lesson. In lesson preparation there is a selection of learning methods. How can the teacher do the learning well if the preparation of planning a lesson is not complete?

The teacher can choose a discussion method such as jigsaw, outdoor class, or other methods that are appropriate and suitable with the basic competence to be taught. It is not appropriate if the outdoor class method or tour work is paired to teach basic competence of 'analyzing the values contained in the literature/novel being read'. Outdoor method which in practice invites students out of class is appropriate to teach basic competence like 'writing poetry', 'writing news text', 'writing observational report text' and other basic competence which can be stimulated by the atmosphere outside the classroom.

\subsubsection{Continue to Develop Themselves through Training and Seminars}

According to Zamroni [21] types of professional work are classified into two, namely hard profession and soft profession. Teachers are included in the category of soft profession. This work requires art in its implementation. Furthermore, Zamroni revealed that as support for improving this competency, there should be seminars, workshops, and other types of training. The fact that teachers still have low competence must be recognized. The 2012 Minister of Education and Culture press conference report quoted by Fajar et al. [22] stated that the average score of the competency test results of senior high school teachers in West Java Province was only 55,35 . This bitter reality is a hard slap to the world of education, including Indonesian language teachers. The most appropriate way is to increase competence through education, training, and actively attending seminars. This competency improvement program for teachers 
is considered independent. Teachers who want to develop, of course always make efforts to improve themselves, such as increasing literacy activities, learning ICT to support their learning activities, as well as active discussion with peers. Syakur's [23] research results showed that $62,15 \%$ of teachers rarely used information technology in learning and $34,95 \%$ of teachers lacked information technology. Whereas one of the competencies that teacher must have as suggested by Selvi [24] is the ability of information and communication technology. How will learning be interesting if the teacher's technological ability is low? In fact, technological ability is very influential on the ability of teachers to prepare learning media. Learning presented with interesting media will make students excited and not easily bored with learning.

Writing training or workshop is one of the activities that is very appropriate to be followed by Indonesian Language teachers because from the results of this training, it is not impossible that it will produce a study paper. If in the material contained in the Basic Competence there are activities to write scientific papers, it is not negotiable that the ability of Indonesian language teachers in writing scientific papers is an obligation. The importance of writing training activities is in line with the solutions offered by Leonard [17] problems of low competence of teaching staff. Classroom Action Research training is one of the recommendations. In line with Leonard's idea, Firmansyah [25] also emphasized that one of the characteristics of professional Indonesian language teachers is those who have made a scientific paper. There have been many journals and spaces provided for teachers to publish their work. But not many teachers take advantage of this opportunity. How can students properly absorb material of writing scientific papers if the teacher has never written scientific papers.

One thing that needs to be underlined in the training activities, seminars, and workshops for teacher is namely to apply their knowledge with full responsibility in lesson. What happens in the field is that not many teachers really apply the learning workshop knowledge properly. On the other hand, after being given training, the teaching style of the teacher is still the same or conventional style, as mocked by Prayitno [26] which was popularized with 'Lima Ha', namely decoration, memorizing, constrained, rebuke, and emptiness (hiasan, hapalah, keharusan, hardikan, and hampaan). The knowledge that has been obtained by the teacher in the seminar, the material that has been spread in guidebooks has not become a spiritual guide in the practice of learning in class.

\subsubsection{Improving Literacy Skills}

It is a fact that Indonesian people do not yet have a good literacy culture. That condition by Purwanto in Nurdiyanti [27] is referred to as the aliterate community, which is people who have the ability to read but have not made reading as an everyday activity or habit. It can be recognized that activities in society are still thick with oral culture rather than reading and writing culture.

The research results by Winiari et al. [28] concerning the difficulty of learning Indonesian in a Piloting Elementary School in the Ginanjar Regency in the 2013 curriculum were difficulties in reading and writing. Of the two aspects, the greatest difficulty is the ability to read. It is clear that literacy skills for students are still a homework for all parties, especially Indonesian Language teachers. These findings are in line with the latest research on literacy skills conducted by Kharizmi [29] which also reveals the fact that literacy skills of students in Indonesia are in the low category. These findings are a bitter reality for the world of Indonesian Language learning. How not? Inevitably it must be admitted that the low literacy ability of these students is a product of the Indonesian learning process. With this reality, there is no other way but to improve the overall literacy skills of Indonesian teachers. The strong expectation was that 
if the teacher's ability in literacy was good, it would be easier for him to guide students to correctly become literate.

The term literacy in the world of Indonesian learning is very familiar. Indonesian language teachers must have good literacy skills. It is non-negotiable. Why? Because how can he/she teach reading and writing well, if the teacher's literacy ability is not good. Literacy according to Musthafa [30] is a combination of competence between reading, writing, and critical thinking. It turns out that proficient reading and writing is not enough. An Indonesian teacher must have critical thinking skills. Critical in absorbing the information obtained. Transfer of literacy learning to students will be easier and in better quality if the teacher has adequate literacy skills. This literacy skill is an inseparable package in learning Indonesian. More importantly, literacy has a very important role for someone in achieving academic success [31]. The higher the literacy, the better the academic ability.

The real program that must be implemented is a culture of literacy from an early age both in schools and in the community spearheaded by Indonesian Language teachers. This early application is because children who are accustomed to reading and writing activities early on will not experience obstacles in literacy activities in their schools [32]. In other words, Indonesian teachers must be an example and literacy activator both in schools and in their communities.

By carrying out the six things described above, it is not impossible that Indonesian language learning will attract and produce student that are proficient in communicating, working, and are critical and polite in their attitude.

\section{Conclusion}

Based on the studies and analyzes conducted, it can be concluded that learning Indonesian language that focuses on text and written communication skills requires an effort to be interesting. Some things that teachers need to do so that Indonesian language learning is interesting include: (1) Mastering Basic Teaching Skills, (2) Preparing attractive learning designs, (3) Preparing traditional and electronic learning media, (4) Choosing appropriate learning methods, (5) Continue to develop themselves through training and seminars, and (6) Improving literacy skills. Based on the conclusions obtained, it is recommended that: (1) Indonesian Language teachers should immediately improve and do 6 things as described above so that Indonesian Language learning is interesting and (2) other subject teachers can adopt 6 things the findings of the analysis of this paper in their teaching assignments.

\section{References}

[1] A. Krishna, "Self Empowerment-Seni Memberdaya Diri bagi Para Pendidik dan Pemimpin," Jakarta: Penebar Swadaya, 2007.

[2] M. Chotib, Gurunya Manusia. Bandung: Mizan Pustaka, 2014.

[3] M. S. Jailani, "Guru profesional dan tantangan dunia pendidikan," Al-Ta lim J., vol. 21, no. 1, pp. $1-9,2014$.

[4] H. Abas, "DIsorientasi Pengelolaan Guru," Harian Kompas, p. 13, 2014.

[5] J. P. Sitorus, "Menjadikan Bahasa Indonesia sebagai Matapelajaran Favorit Siswa," Harian Kompas, 2015.

[6] I. N. Sumayasa, M. A. P. A. A. I. N. Marhaeni, and N. Dantes, "Pengaruh Implementasi Pendekatan Saintifik Terhadap Motivasi Belajar dan Hasil Belajar Bahasa Indonesia pada Siswa 
Kelas VI di Sekolah Dasar Se Gugus VI Kecamatan Abang, Karangasem.” Ganesha University of Education, 2015.

[7] Slamet, "Dasat-dasar Pembelajaran Bahasa dan Sastra Indonesia di Sekolah." Lembaga Pengembangan Pendidikan dan UPT Penerbitan UNS/UNS Pres, Surakarta, 2007.

[8] Atmazaki, "Mengungkap Masa Depa: Inovasi Pembelajaran bahasa Indonesia dalam Konteks Pengembangan karakter Cerdas." Universitas Negeri Padang, Padang, 2013.

[9] Mahsun, Teks Pembangun Bahasa Indonesia Kurikulum 2013. Jakarta: Raja Grafindo Persada, 2014.

[10] Kunandar, Guru professional. Jakarta: PT Raja Grafindo Persada, 2007.

[11] Ngatmini, “Analisis Keterampilan Guru Bahasa Indonesia dalam Mengaplikasikan Keterampilan dasar Mengajar di SLTP dan SLTA Kota Semarang," in Proseding PIPSI XXXVII, 2016.

[12] M. U. Usman, "Menjadi guru profesional," 2006.

[13] P. M. Barbetta, K. L. Norona, and D. F. Bicard, "Classroom behavior management: A dozen common mistakes and what to do instead," Prev. Sch. Fail. Altern. Educ. Child. Youth, vol. 49, no. 3, pp. 11-19, 2005.

[14] V. Rahmayanti, "Pengaruh minat belajar siswa dan persepsi atas upaya guru dalam memotivasi belajar siswa terhadap prestasi belajar bahasa Indonesia siswa SMP di Depok," SAP (Susunan Artik. Pendidikan), vol. 1, no. 2, 2016.

[15] B. Ruwanto, "Buku teks Kurikulum 2013.” Kedaulatan Rakyat, Yogyakarta, 2013.

[16] D. Rosyada, "Paradigma Pendidikan Demokratis: Sebuah Model Pelibatan Masyarakat dalam Penyelenggaraan Pendidikan.” PT Kencana, Jakarta, 2004.

[17] L. Leonard, "Kompetensi tenaga pendidik di Indonesia: Analisis dampak rendahnya kualitas SDM guru dansolusi perbaikannya," Form. J. Ilm. Pendidik. MIPA, vol. 5, no. 3, pp. 192-201, 2015.

[18] P. Suparno, Guru demokratis di era reformasi pendidikan. Gramedia Widiasarana Indonesia, 2004.

[19] M. Dalyono, Psikologi Pendidikan. Jakarta: Rineka Cipta, 2009.

[20] S. Pujiono, "Kesiapan guru bahasa Indonesia SMP dalam implementasi Kurikulum 2013," Litera, vol. 13, no. 2, 2014

[21] Zamroni, Paradigma Pendidikan Masa Depan. Jakarta: Proyek DPP SMU, 2003.

[22] M. Y. Fajar, O. Rohaeni, Y. Permanasari, A. Iswani, and K. Mulkiya, "Meningkatkan Kompetensi Guru SMA dan Sederajat Melalui Pelatihan Pembelajaran Berbasis TIK," ETHOS J. Penelit. dan Pengabdi. Kpd. Masy., vol. 5, no. 2, pp. 175-181, 2017.

[23] I. A. Syukur, "Profesionalisme guru dalam mengimplementasikan teknologi informasi dan komunikasi di kabupaten nganjuk," J. Pendidik. dan Kebud., vol. 20, no. 2, pp. 200-210, 2014.

[24] K. Selvi, “Teachers' competencies," Cult. Int. J. Philos. Cult. Axiolog., vol. 7, no. 1, pp. 167$175,2010$.

[25] M. B. Firmansyah, "Pengembangan Profesionalitas Guru Bahasa Indonesia." STKIP PGRI Pasuruan Jawa Timur, 2018.

[26] Prayitno, Dasar Teori dan Praksis Pendidikan. Jakarta: Gramedia, 2009.

[27] E. Nurdiyanti and E. Suryanto, "Pembelajaran literasi mata pelajaran bahasa indonesia pada siswa kelas V sekolah dasar," Paedagogia, vol. 13, no. 2, 2010.

[28] I. G. A. Winiari, I. G. Meter, I. G. A. O. Negara, and S. P. M. Ke, “Analisis Kesulitan-Kesulitan Belajar Bahasa Indonesia Kelas V Dalam Implementasi Kurikulum 2013 Di SD Piloting SeKabupaten Gianyar," Mimb. PGSD Undiksha, vol. 3, no. 1, 2015.

[29] M. Kharizmi, "Kesulitan siswa sekolah dasar dalam meningkatkan kemampuan literasi," $J$ Pendidik. Dasar, vol. 2, no. 2, 2015.

[30] B. Musthafa, "Literasi dini dan literasi remaja: Teori, Konsep, dan Praktik," Bandung: Crest, 2014.

[31] A. R. Farihatin, "Kegiatan membaca buku cerita dalam pengembangan kemampuan literasi dasar anak usia dini." Universitas Muhammadiyah Surakarta, 2013.

[32] C. J. Lonigan, "Development, assessment, and promotion of preliteracy skills," Early Educ. Dev., vol. 17, no. 1, pp. 91-114, 2006. 